\title{
循環器疾患随伴後天性フォンウィルブランド 症候群の臨床的インパクト
}

堀内久徳 ${ }^{*}$, 松本雅則 ${ }^{2}$, 小亀浩市 ${ }^{3}$

\section{Clinical impact of acquired von Willebrand syndrome associated with cardiovascular diseases}

Hisanori HoRIUCHI, Masanori MatsumOto, Koichi KoKAME

要約：生体内において過度の高ずり応力が生じる循環器疾患では, 止血機能 に重要なフォンウィルブランド因子 $(\mathrm{VWF})$ の機能異常が生じ, 出血性疾患 である後天性フォンウィルブランド症候群 (AVWS) が発症する場合がある. 重症大動脈弁狭窄症では大半が血液学的にAVWS を合併しているが，肺高 血圧等では頻度が不明である，近年機械的補助循環は重症心不全の治療に大 きく貢献してきたが，ほとんどの場合高度の AVWS を合併する。これまで あまり注目を集めてこなかったが, 高ずり応力による AVWS の臨床的イン パクトは非常に大きく, 早急に疾患毎に実態を明らかにして, 診断法・対応 法を構築することが重要である.

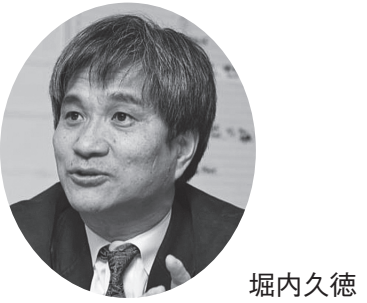

1984年 京都大学医学部医学科 1984 6年 天理よろづ相談所病 院

1986 9年 社会保険小倉記念病 院循環器科

1989 93年 京都大学大学院医 学研究科博士課程

1993 6年 欧州分子生物学研究 所

1996 2004年 京都大学大学院 医学研究科助手 (老年科)

2004 10年 同助手・講師 (循環 器内科学)

2010年 東北大学加齢医学研究 所教授

現在に至る

Key words: von Willebrand factor, shear stress, multimer, Heyde's syndrome, left ventricular assist device (LVAD)

\section{1.はじめに}

止血に重要なフォンウィルブランド因子(VWF)は, 血管内皮細胞や巨核球で巨大多量体として産生され, ずり応力依存的にその特異的切断酵素 ADAMTS13 によって切断され，血中では 2-80サブユニットか らなる多量体として存在する(図 1). 止血機能には 高分子領域の多量体が重要であり ${ }^{1)}$, 高分子領域の VWF の減少・攵損は出血性疾患である 2 型のフォン ウィルブランド病となる。生体内で高ずり応力が発

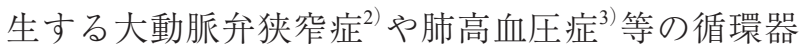
疾患では, 過度の切断が生じ, VWF 高分子多量体

\footnotetext{
1 東北大学加齢医学研究所基礎加齢研究分野

2 奈良県立医科大学輸血部

${ }^{3}$ 国立循環器病研究センター分子病態部

*責任者連絡先 :

東北大学加齢医学研究所基礎加齢研究分野

干 980-8575 仙台市青葉区星陵町 4-1

Tel: 022-717-8463, Fax: 022-717-8463

E-mail: hisanori.horiuchi.e8@tohoku.ac.jp
}

欠損による後天性フォンウイルブランド症候群 (acquired von Willebrand syndrome; AVWS) となる。さら に, 重症心不全の治療に最近, 経皮的心肺補助 (percutaneous cardiopulmonary support; PCPS) や植込型左 室補助人工心臓 (left ventricular assist device; LVAD) 等による機械的補助循環が大きく貢献しているが, その装置内では非常に強いずり応力が生じており， AVWS が発症する4). 本総説では, 高ずり応力が体 内の生じる種々の循環器疾患に随伴する後天性 フォンウィルブランド症候群について概説する.

\section{2. 合併する疾患とその推定症例数・対処法など}

\section{1）大動脈弁狭窄症・閉塞性肥大型心筋症}

高齢者の大動脈弁狭窄症は動脈硬化を基盤に発症 する場合が多く，高齢化が進む我が国では著しく増 加している，以前より，Heyde 症候群として消化管 出血の合併を認めることが知られている5゙が，我が 国の診療現場にその理解が浸透しているとはいいが 


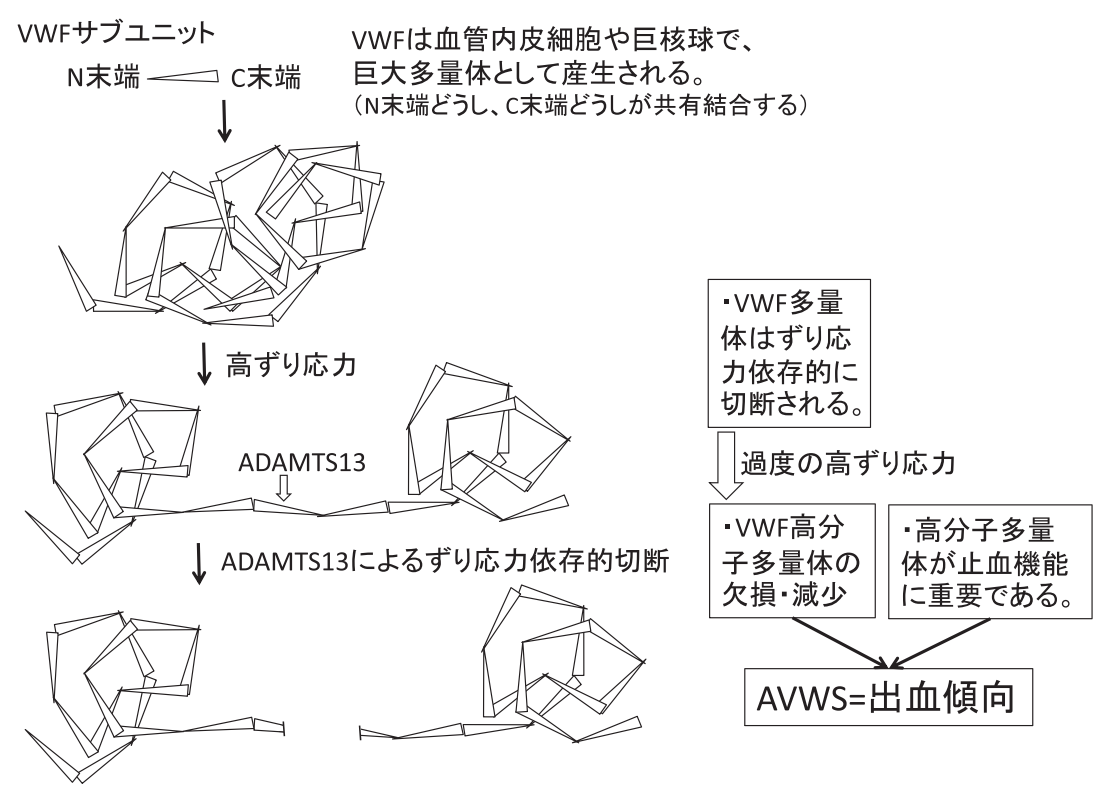

図 1 過度の高ずり応力が引き起こす AVWS

止血因子VWF は血管内皮細胞や巨核球で, 巨大多量体として産生され，血中に放出さ れる，その後，ずり応力依存的に特異的切 断酵素 ADAMTS13 によって切断され，血 中では 2-80 サブユニットからなる多量体 として存在する。過度に強いずり応力があ れば，切断が充進し，高分子領域の多量体 が欠損・減少する。一方，高分子領域の多 量体が止血機能に重要であり, 高分子領域 の多量体が久損・減少は出血傾向である AVWS を引き起こす。

たい，この理解が久如すれば，AVWS を合併する重 症大動脈弁狭窄症の高齢者が, 下血のために入院し, 胃・大腸カメラで癌などの出血性病変を見いだせな かった場合，大動脈弁狭窄症のため積極的な精査や 治療がなされず，下血を繰り返しながら経過観察を されてしまう。しかし, Heyde 症候群の認識があれ ば，適切な治療である大動脈弁置換術がまず選択さ れる。最近では, 経カテーテル的大動脈弁留置術 (transcatheter aortic valve implantation; TAVI) も行われ るようになっている ${ }^{6}$ ，過度のずり応力発生源が弁 置換やTAVIによって取り除かれると，速やかに VWF 高分子多量体は回復する7)。後述のように, VWF large multimer index と名付けた指標によって定 量評価すると, 図 2 のように, 大動脈弁部の最大圧 較差 $50 \mathrm{mmHg}$ の重症大動脈弁狭窄症の大半が血液 学的にはAVWS を発症している ${ }^{8)}$. この結果より推 測すると，我が国には数万人の AVWS 症例が存在す る可能性がある，消化管出血は，後述のように，消 化管血管異形成 (angiodysplasia) からの出血が多いと 報告されている ${ }^{2)}$ ，現在，どのくらいの頻度で出血 を来すのか，どのような症例に出血が生じてくるの か不明であり，実態の解明が必要である。閉塞性肥 大型心筋症 (hypertrophic obstructive cardiomyopathy; HOCM) は肥厚心筋のため, 左室腔内で圧較差が生 じる疾患であり，時に $100 \mathrm{mmHg}$ を超すこともある.
HOCM でも AVWS が合併することがある99.

\section{2) 肺高血圧症}

肺高血圧症ではその疾患進展抑制をめざして抗凝 固療法が行われることが多い，その一方で，喀血と いう重篤な出血性合併症を来すことがある。この肺 高血圧症でもAVWS 発症の報告がある ${ }^{3)}$ ，肺高血圧 症では，重症大動脈弁狭窄症のように大半が AVWS を合併しているようではないが，AVWS 合併例に対 する強い抗凝固療法は, 出血性合併症のリスクを上 昇させている可能性がある。そのため，早急に，肺 高血圧症に打けるAVWS の合併頻度，AVWS 合併 時の出血性合併頻度について明らかにする必要があ ろう。肺高血圧症における AVWS も高ずり応力によ ると考えると，どこで過度のずり応力が生じている のであろう？ 肺血管床の可能性もあるが，三尖弁 閉鎖不全が必発であり，それが原因となっている可 能性もあろう。三尖弁では閉鎖不全が必然的に生じ て求り, 最大圧較差 $(\mathrm{mmHg})$ は $4 \mathrm{v}^{2}(\mathrm{v}$ は流速, $\mathrm{m} /$ 秒 $)$ と近似されるので，最大圧較差 $100 \mathrm{mmHg}$ あれば $5 \mathrm{~m} /$ 秒の流速が生じていることになる。なお，肺高 血圧の薬郕による改善によって, AVWS の改善も 報告されている3)．また，睡眠時無呼吸症候群に伴 うAVWSの合併が報告されている ${ }^{10)}$ ，睡眠時無呼 吸症候群では，無呼吸時に肺高血圧状態になってい るので，肺高血圧症が AVWS を引き起こしている 
A.

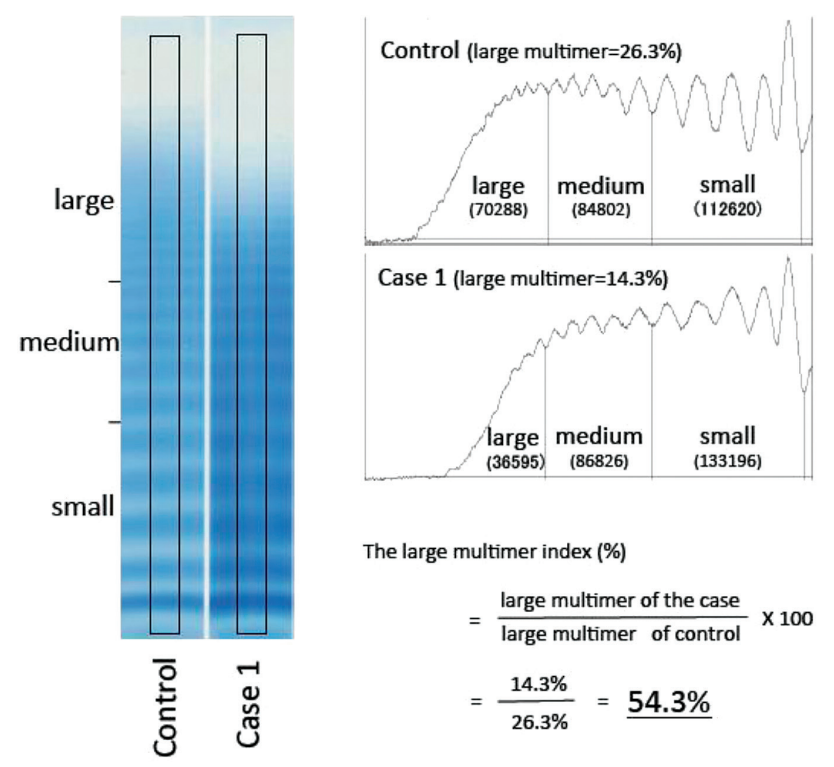

B.

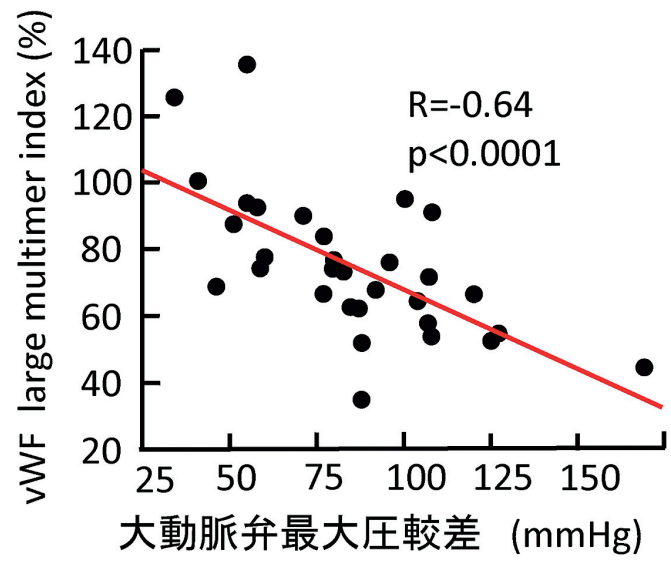

図 2 重症大動脈弁狭窄症症例における VWF large multimer index (文献 8 より改変)

(A) VWF large multimer index の計算法. まず，症例および対照健常人の血漿でVWF 多量体解析を行い，その結果 を densitometry によって解析してそれぞれ高分子量 (large) 領域の割合をそれぞれ求める。そして症例のVWF 高分 子多量体の割合を，対照健常人の VWF 高分子多量体の割合で除した值を VWF large multimer index とする。この方 法によって，健常人を $100 \%$ としたときの，症例のVWF 高分子量多量体の量を表現することができる。（B）重症大 動脈弁狭窄症に打けるVWF large multimer index. 大動脈弁狭窄症の重症度(圧較差)依存的に, AVWS が発症してい ることが明らかとなった。

のかもしれない.

\section{3）僧帽弁閉鎖不全}

僧帽弁閉鎖不全症 53 例を心エコーと共にVWF 多 量体解析を行い, 軽症では 8\%, 中等症では 64\%, 重症では $85 \%$ の症例にAVWS を認め, 7 例 (13\%) に消化管血管異形成と輸血を要する消化管出血を認 めたと報告されている ${ }^{11}$ 。僧帽弁閉鎖不全症の罹患 症例は非常に多く, 早急な検証が必要である。

\section{4）先天性心疾患}

心室中隔欠損症や動脈管開存症, ファロー四徵症 等では体内に高流速が生じ，非常に強いずり応力が 生じる。先天性心疾患に合併する 11 例の AVWS の 報告では, 脳出血, 下血, 出血性脳梗塞をそれぞれ 1 名ずつ認めていることが報告されている ${ }^{12)}$.

\section{5）機械的補助循環}

急性心筋梗塞後等の重篤な急性心不全の治療に体 外式人工肺 ECMO や PCPS が貢献してきた。多く の場合，穿刺部等より出血が生じ，時に重症化する が，同時に施行される抗凝固療法のためと考えられ
てきた，ECMO では高度の AVWS が生じていること が報告されており ${ }^{13)}$ ，その出血にAVWS が関与して いる可能性は高い，末期心不全の治療として心移植 が行われる。我が国では臓器移植法の改定が 2011 年に行われて症例数の増加が期待されたが, 最近で は年間 40 例弱で横ばいとなっている。一方, LVAD の発展はめざましく，定常流を採用することによっ て小型化が可能となり, 我が国でも2011 年より心 移植へのつなぎ (bridging) として植込型 LVAD が認 可された。植达型 LVADで治療された症例は退院可 能となり，普通に生活できるようになる，QOL は 格段に向上されるため, 症例は増加しており, 2015 年には 132 例が治療された (http://www.pmda.go.jp/ safety/surveillance-analysis/0009.html). 現在も急速な 進歩が進んで怙り，今後さらに多くの症例が植込型 LVAD で治療されるようになるであろうＬVVADの 主たる合併症は, 感染, 塞栓, そして出血である。 現在の植込型 LVAD では，バッテリーやコントロー ラーは体外にあり，植え込まれた LVAD と皮膚を 
介してドライブラインで結ばれている。感染の多く はこのドライブライン感染である。塞栓は LVAD と いう生体異物内での血栓が原因となる。出血は直後 より生じる場合もあるが，1 年を経てから発生する 場合もある。施行される抗凝固療法や抗血小板療法 が原因と考えられてきたが，過度な強度でない場合 にも出血は生じており, 最近では植込型 LVAD 内の 非常に高いずり応力による AVWS が主たる原因と考 えられている ${ }^{14,15)}$ 。われわれも最近，植込型 LVAD 装着後 1 カ月より出血を来し, その制御が困難で あった症例を経験した ${ }^{16)}$. LVAD に伴う AVWS は全 例に生じ，大動脈弁狭窄症例と比べて VWF 高分子 多量体の欠損の程度は非常に高度である (Sakatsume et al, 論文執筆中). 定常流型 LVAD のポンプは遠心 型と軸流型に分類される。遠心型はポンプ内で羽根 車がその外側に血液を直接送り出して血流を生み出 すのに対して，軸流型では羽根車が船のスクリュー のように作用して血流を生み出す。遠心型と比べて 軸流型ポンプの回転数は高く, より高度な AVWS が発生する ${ }^{17)}$ 。なお，出血部位としては消化管出血 が多い，消化管出血は，大動脈弁狭窄症同様に血管 異形成からが多いと考えられている。

\section{3. 診断法の問題点とその解決策}

上記の循環器疾患に伴う AVWS は, VWF 多量体 解析で診断されるが，それは最大分子量 2000 万夕゙ ルトンという超巨大分子のウェスタンブロットであ り，高度の技術を要する。そのため，本質的には同 じであっても施設毎で施行法が少しずつ異なり, 結 果にも若干の影響を及ぼている。また，多くの場 合定量的評価がなされず, AVWSの有無が定性的 に議論されてきた。 AVWS の診断はウェスタンブ ロットを評価し，高分子多量体の減少・尔損を評価 することで可能である。しかし，ウェスタンブロッ 卜の評価に精通していない臨床医には，困難を伴う と思われる。検査值としては，健常人を基準とした VWF 高分子多量体量を臨床検査值として数字で評 価できれば，診療現場では広く用いられるようにな るであろう。

現在われわれは，VWF 高分子多量体量を臨床検 査值として評価できるよう，SDS-アガロースゲル
電気泳動によるVWF 多量体解析の標準化を進めて いる。多量体の泳動像に大きな影響を及ぼすアガ ロース濃度は $1.2 \%$ に統一している。標準血漿およ び患者血漿中のVWF 抗原量をあらかじめ定量して おき，等量のVWF 抗原量になるように標準血漿と 患者血漿の泳動量を調節し, 隣接レーンで比較解析 する。一次抗体の種類を統一し，HRP 標識二次抗 体を用いた化学発光による多量体バンドの検出およ び定量には，X線フィルムではなくイメージアナラ イザ(例えばLAS 4000)を用いる。ささらに，後述の 定量化には，最小単位である VWF ダイマーの特定 （意外に難しい)が重要であるため，その特定には慎 重を期することとした，定量法(数值化)には，VWF large multimer index を用いる7). ダイマーのバンド を1 番として低分子量側から数え，1～5 番を低分 子領域，6〜10 番を中分子領域，11 番以上のすべて を高分子領域と呼ぶ。イメージアナライザで各領域 のシグナル強度を取得し，標準血漿において高分子 領域の強度が全体(3 領域の合計)の 20-30\% (目標は $25 \%)$ となるように像を調整した上で，隣接レーン の患者血漿の高分子領域の割合を求める。その值 を，標準血漿の高分子領域の值 (20-30\%) で除し，\% 表示したものを VWF large multimer index と定義す る(図 2)。このindex を用いることによって，施設 間や検査者間，日差等の影響をできるだけ排除し， 標準血漿を $100 \%$ としたときの患者 VWF 高分子多 量体量を\%表示で定量評価することができる。この 方法で施設間のばらつきが減少し，患者高分子多量 体を評価できるようになることをすでに確認してい る。この方法を完成させ，近々に論文発表したいと 考えている.

\section{4. 消化管血管異形成の形成メカニズム}

循環器疾患に伴う AVWS での出血では，消化管 出血が多いのが特徴である。そして消化管出血は通 常血管異形成からのものである，消化管血管異形成 (angiodysplasia) は粘膜の毛細血管の拡張としてとら えられ，小腸を含むすべての消化管に生じる，その ため, 循環器疾患に伴うAVWS からの出血では小 腸の検索も重要である，消化管血管異形成は加齢と 共に増加する。大動脈弁狭窄症に随伴する消化管血 


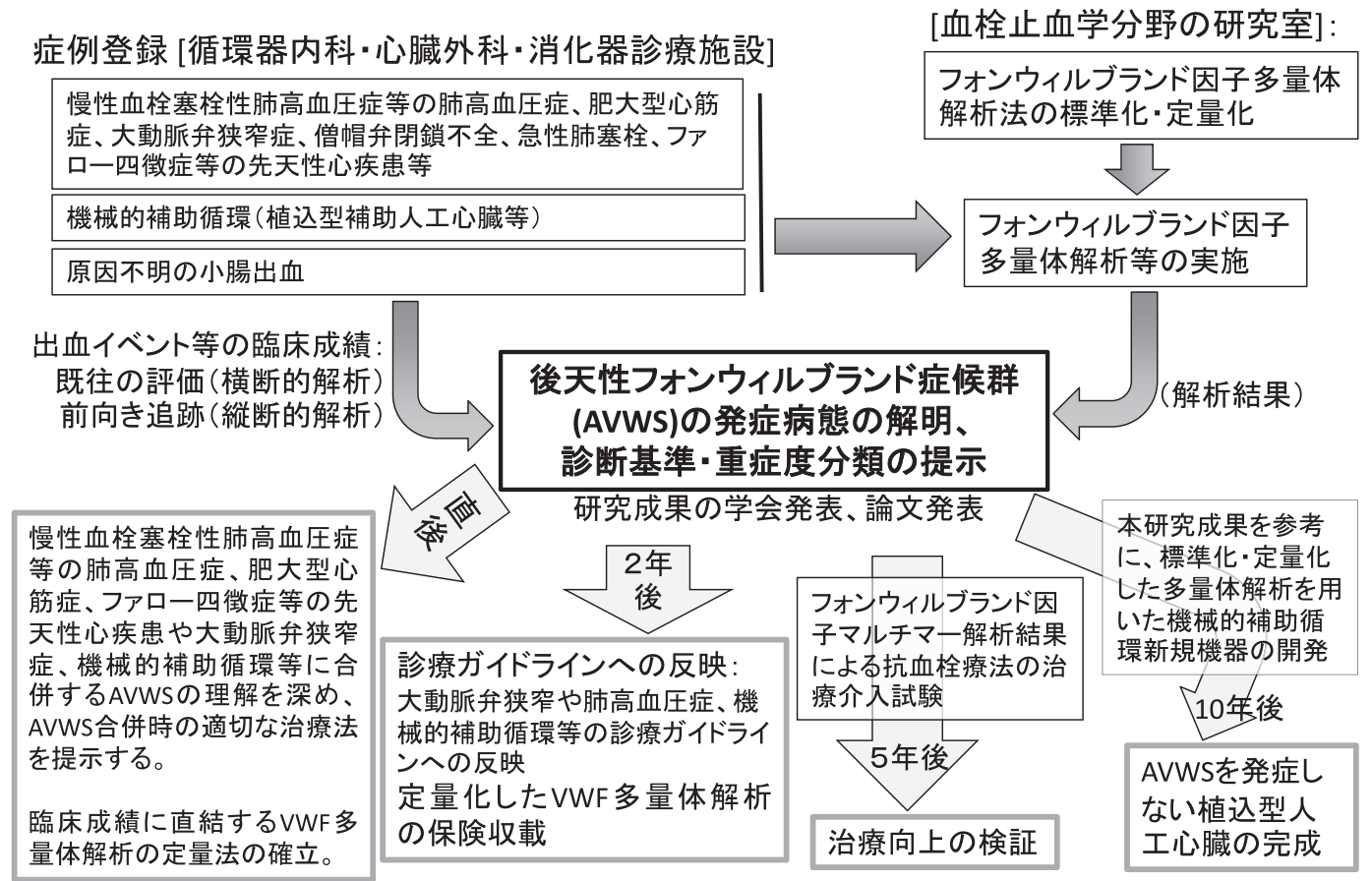

図 3 The AVeC Study の研究計画ロードマップ

管異形成は，大動脈弁狭窄症自体が高齢者に多く発 症・進展する疾患であるため, 消化管血管異形成も 高齢によって生じるものとも考えられてきた。しか し，LVAD が装着された若年者でも消化管血管異形 成は生じており，脈圧消失・低血圧による組織灌流 障害や虚血によるVEGF 発現調節を介した血管新 生が原因かもしれない。一方, VWF と血管新生や 血管異形成との関連も論じられており ${ }^{18)}$, VWF 高 分子多量体の減少が血管新生を促進しているのかも しれない，この消化管血管異形成の形成メカニズム は未だ不明であり, 今後の研究が必須である。

\section{5. おわりに}

これまで述べてきたように，種々の循環器疾患に AVWS が随伴する。この疾患合併の臨床的インパ クトは非常に大きいにもかかわらず，診療現場でほ とんど認識されていない。われわれは，循環器・消 化器の診療科とともに種々の疾患を登録し, 標準化 したVWF 多量体解析法によって定量化して，横断 的・縦断的解析によって循環器疾患に随伴する AVWS の実態を明らかにしょうとする多施設共同
前向き臨床研究 acquired von Willebrand syndrome coexisting with cardiovascular diseases study (The AVeC Study)を開始した（図 3)。近い将来に改めてその結 果を報告できればと考えている。循環器疾患に随伴 する AVWS が広く理解され，適切な診療方針が選 択されるようになることを期待する。

謝辞

VWF 多量体解析の標準化に関する研究や The AVeC Study は, 厚生労働省科学研究費, 日本血栓 止血学会研究促進費, 東北大学加齢医学研究所共同 利用研究費, 先進医薬研究振興財団, 鈴木謙三記念 医科学応用研究財団の支援を受けており，深謝致し ます。

著者全員の利益相反 $(\mathrm{COI})$ の開示 :

本論文発表内容に関連して開示すべき企業との利益 相反なし

\section{文献}

1) Matsumoto M, Kawaguchi S, Ishizashi H, Yagi H, Iida J, 
Sakaki T, Fujimura Y: Platelets treated with ticlopidine are less reactive to unusually large von Willebrand factor multimers than are those treated with aspirin under high shear stress. Pathophysiol Haemost Thromb 34: 35-40, 2005.

2) Loscalzo J: From clinical observation to mechanism-Heyde's syndrome. N Engl J Med 367: 1954-1956, 2012.

3) Veyradier A, Nishikubo T, Humbert M, Wolf M, Sitbon O, Simonneau G, Girma JP, Meyer D: Improvement of von Willebrand factor proteolysis after prostacyclin infusion in severe pulmonary arterial hypertension. Circulation 102: 24602462, 2000.

4) Suarez J, Patel CB, Felker GM, Becker R, Hernandez AF, Rogers JG: Mechanisms of bleeding and approach to patients with axial-flow left ventricular assist devices. Circ Heart Fail 4: 779-784, 2011.

5) Heyde EC: Gastrointestinal bleeding in aortic stenosis. $\mathrm{N}$ Engl J Med 259: 196-196, 1958.

6) Spangenberg T, Budde U, Schewel D, Frerker C, Thielsen T, Kuck KH, Schäfer U: Treatment of acquired von Willebrand syndrome in aortic stenosis with transcatheter aortic valve replacement. JACC Cardiovasc Interv 8: 692-700, 2015.

7) Yamashita K, Yagi H, Hayakawa M, Abe T, Hayata Y, Yamaguchi N, Sugimoto M, Fujimura Y, Matsumoto M, Taniguchi S: Rapid restoration of thrombus formation and high-molecular-weight von Willebrand factor multimers in patients with severe aortic stenosis after valve replacement $J$ Atheroscler Thromb in press, 2016.

8) Tamura T, Horiuchi H, Imai M, Tada T, Shiomi H, Kuroda M, Nishimura S, Takahashi Y, Yoshikawa Y, Tsujimura A, Amano M, Hayama Y, Imamura S, Onishi N, Tamaki Y, Enomoto S, Miyake M, Kondo H, Kaitani K, Izumi C, Kimura T, Nakagawa Y: Unexpectedly high prevalence of acquired von Willebrand syndrome in patients with severe aortic stenosis as evaluated with a novel large multimer index. J Atheroscler Thromb 22: 1115-1123, 2015.

9) Pruthi RK: Hypertrophic obstructive cardiomyopathy, acquired von Willebrand syndrome, and gastrointestinal bleed- ing. Mayo Clin Proc 86: 181-182, 2011.

10) Koyama N, Matsumoto M, Tamaki S, Yoshikawa M, Fujimura Y, Kimura H: Reduced larger von Willebrand factor multimers at dawn in OSA plasmas reflect severity of apnoeic episodes. Eur Respir J 40: 657-664, 2012.

11) Blackshear JL, Wysokinska EM, Safford RE, Thomas CS, Shapiro BP, Ung S, Stark ME, Parikh P, Johns GS, Chen D: Shear stress-associated acquired von Willebrand syndrome in patients with mitral regurgitation. J Thromb Haemost 12: 1966-1974, 2014.

12) Onimoe G, Grooms L, Perdue K, Ruymann F: Acquired von Willebrand Syndrome in congenital heart disease: does it promote an increased bleeding risk? Br J Haematol 155: 622624, 2011.

13) Kalbhenn J, Schmidt R, Nakamura L, Schelling J, Rosenfelder S, Zieger B: Early diagnosis of acquired von Willebrand Syndrome (AVWS) is elementary for clinical practice in patients treated with ECMO therapy. J Atheroscler Thromb 22: 265271, 2015.

14) Slaughter MS: Hematologic effects of continuous flow left ventricular assist devices. J Cardiovasc Translat Res 3: 618$624,2010$.

15) Draper KV, Huang RJ, Gerson LB: GI bleeding in patients with continuous-flow left ventricular assist devices: a systematic review and meta-analysis. Gastrointest Endosc 80: 435446.e1, 2014.

16) Sakatsume K, Akiyama M, Saito K, Kawamoto S, Horiuchi H, Saiki Y: Intractable bleeding tendency due to acquired von Willebrand syndrome after Jarvik 2000 implant. J Artif Organs in press, 2016.

17) Meyer AL, Malehsa D, Budde U, Bara C, Haverich A, Strueber M: Acquired von Willebrand syndrome in patients with a centrifugal or axial continuous flow left ventricular assist device. JACC Heart Fail 2: 141-145, 2014.

18) Randi AM, Laffan MA, Starke RD: Von Willebrand factor, angiodysplasia and angiogenesis. Mediterr J Hematol Infect Dis 5: e2013060, 2013. 